\title{
Fundamentals of Volunteer Orientation ${ }^{1}$
}

\author{
Olivia Caillouet, Jessica Williams, Shelby Atwood, and Matt Benge ${ }^{2}$
}

\section{Introduction}

In 2018, over 77 million adults volunteered in the United States, dedicating approximately 7 billion hours valued at around $\$ 167$ billion (Corporation for National \& Community Service, 2018). Volunteers typically come from various ages, backgrounds, and levels of knowledge. Because of this diversity, organizations should provide volunteers an orientation to help introduce them to the organization (Culp et al., 2005; Ouellette et al., 2014). Volunteers have been described as the "glue that holds a community together" (Western Connecticut State University, n.d., para. 1), and the ideal relationship between an organization and volunteer is mutually beneficial. We created this fact sheet to assist volunteer managers when creating volunteer orientations for their new volunteers.

\section{Importance of Orienting Volunteers}

Volunteer training and orientation are critical components that should promote volunteers' understanding of the role they hold within organizations (Fox et al., 2009). "Orientation programs help volunteers feel more comfortable and confident in their capacity to accomplish the assigned work, helping volunteers understand how their tasks contribute to holistic organizational goals and objectives" (Edwards, 2012, p. 229). Many organizations do not have specific orientation procedures in place, which can be detrimental to sustaining long-term volunteers (Ouellette et al., 2014).
Naylor (1973) supported the need for effective volunteer orientations and argued that poorly trained volunteers can even harm organizations. In fact, without a proper volunteer orientation, volunteers can even feel confused or lost in their role.

Volunteer orientation can look very different depending on the organization (Edwards, 2012). Some organizations offer in-person sessions consisting of a couple hours or even a day-long orientation that provides all of the information about the organization along with a tour of the facilities and planned activities for the volunteers. Smaller organizations may choose to do a tour and information session about the program outlining expectations and roles of volunteers. Others may choose to create a video that describes the program and provides the volunteer a virtual tour of the organization. Nevertheless, the quality of the orientation matters and will reflect how the volunteer succeeds within the program.

Volunteer orientation should provide "time for volunteers to connect personally with the mission and vision of the organization, and to develop feelings of belonging and confidence related to their work" (Edwards, 2012, p. 229). If the orientation does not take place or is of poor quality, future organizational efforts could become more complicated, such as through increased risk (e.g., failure to follow dress code on farms where tools could be harmful), and/or create time management issues with retraining volunteers. Along the same lines, Snider (1985) explains

1. This document is AEC720, one of a series of the Department of Agricultural Education and Communication, UF/IFAS Extension. Original publication date February 2021. Visit the EDIS website at https://edis.ifas.ufl.edu for the currently supported version of this publication.

2. Olivia Caillouet, graduate assistant, Department of Agricultural Education and Communication; Jessica Williams, graduate student, Department of Agricultural Education and Communication, and Extension program assistant, Department of Family, Youth and Community Sciences; Shelby Atwood, graduate student; and Matt Benge, assistant professor, Department of Agricultural Education and Communication; UF/IFAS Extension, Gainesville, FL 32611.

The Institute of Food and Agricultural Sciences (IFAS) is an Equal Opportunity Institution authorized to provide research, educational information and other services

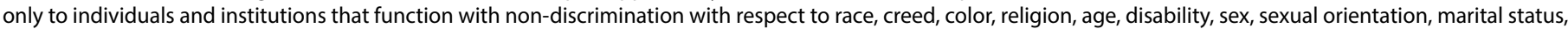
national origin, political opinions or affiliations. For more information on obtaining other UF/IFAS Extension publications, contact your county's UF/IFAS Extension office. U.S. Department of Agriculture, UF/IFAS Extension Service, University of Florida, IFAS, Florida A \& M University Cooperative Extension Program, and Boards of County Commissioners Cooperating. Nick T. Place, dean for UF/IFAS Extension. 
that volunteer training increases the chances of sustaining organizations for several reasons: (a) a clearer understanding of the organization's mission and goals, (b) greater volunteer ownership, (c) more program diversity, and (d) an increased number of advocates for the organization. Both the volunteers' and organization's needs should guide the orientation program.

\section{Application to Volunteer Organizations}

The proper implementation of an effective volunteer orientation program can save an organization resources while preventing future hardships. "Orientation can contribute to the avoidance of problems in the future by helping volunteers and staff understand rules, policies, and available resources" (Edwards, 2012, p. 229). There are many different needs addressed in a volunteer orientation. An orientation agenda could include time for

- educating potential volunteers (e.g., mission, values, history, etc.),

- interactions between new volunteers and staff members and other volunteers, and

- a tour of the facility to help guide new volunteers (Edwards, 2012).

There are no set answers regarding the type of volunteer orientation an organization should have, but the organization should decide the most effective method of delivery (Community Toolbox, n.d.); however, simply "having" an orientation is not enough. Ideally, organizations should use a variety of methods to cover each component listed in Table 1, but that could take more time than is available to the organization and volunteers. Therefore, according to McCurley and Lynch (2006), volunteers should receive three primary orientation components regardless of the volunteer orientation length:

\section{Cause orientation}

\section{System orientation}

\section{Social orientation}

Cause Orientation helps volunteers understand the mission, vision, and purpose of the organization. Why am I here? Content could include the (a) organizational history, (b) future plans, (c) current projects, or (d) target client descriptions (Edwards, 2012). This type of orientation should provide the volunteers with the ability to connect emotionally to the organization and its purpose (Edwards, 2012).

System Orientation "is the management or procedural information the volunteer will need to be successful in working with the organization" (Edwards, 2012, p. 231). Content such as (a) supplies, (b) networks, (c) roles, and (d) policy standards should be covered (Edwards, 2012).

Social Orientation "supports volunteers in their understanding of the organizational culture" (Edwards, 2012, p. 231). Through this aspect of orientation, volunteers should have the opportunity to learn names of supervisors, volunteers, and other staff in addition to content such as dress codes and work etiquette (Edwards, 2012).

Edwards (2012) explained, "by encompassing all three aspects of orientation in a systematic approach, volunteers are more likely to receive the emotional and informational support needed to be successful in their work assignments" (p. 231).

There are many methods for communicating an organization's vision and mission, but these methods are insufficient if the proper content is not provided to new volunteers. To achieve the goal of an effective volunteer orientation, organizations should implement recommendations regarding broad-agenda components of orientation sessions (see Table 1). Volunteer coordinators should use Table 1 to determine what is feasible to offer during their organization's volunteer orientation based on several factors: (a) volunteer needs, (b) organizational needs, (c) time, and (d) available resources. Furthermore, volunteer coordinators should use Table 1 to ensure all three primary orientation components (cause, system, and social) are offered at least once.

\section{Conclusion}

Organizations can gain many benefits from volunteers; however, the use of volunteers takes time and resources and requires adequate training, or else using volunteers can be more time-consuming than originally planned (Benjamin, 2018). Leaders of volunteer organizations must ensure their organizations have adequately prepared volunteers to carry out the organization's mission. Last, volunteer leaders should incorporate the cause, system, and social orientation components to effectively create an orientation focused on providing the appropriate onboarding of their most valuable asset-volunteers. 


\section{References}

Benjamin, T. (2018). Advantages \& disadvantages of using volunteers in work settings. https://smallbusiness.chron. com/advantages-disadvantages-using-volunteers-worksettings-36680.html

Community Toolbox. (n.d.). Developing volunteer orientation programs. https://ctb.ku.edu/en/table-of-contents/ structure/volunteers/orientation-programs/main

Corporation for National \& Community Service. (2018). Volunteering in the U.S. hits record high; worth $\$ 167$ billion. https://www. nationalservice.gov/newsroom/press-releases/2018/ volunteering-us-hits-record-high-worth-167-billion

Culp, K., Aldenderfer, A. E., Allen, L. A., Fannin-Holliday, S. G., Ford, R. C., \& Goodwin, C. A. (2005). Orchestrating volunteer orientation: Introducing the O.B.O.E. Model. Journal of Extension, 43(6). https://www.joe.org/ joe/2005december/tt5.php

Edwards, H. C. (2012). Orientation. In T. D. Connors (Ed.), The volunteer management handbook: Leadership strategies for success (2nd ed., pp. 227-236). John Wiley \& Sons.

Fox, J., Hebert, L., Martin, K., \& Bairnsfather, D. (2009). An examination of the benefits, preferred training delivery modes, and preferred topics of 4-H youth development volunteers. Journal of Extension, 47(1). https://www.joe.org/ joe/2009february/rb2.php

McCurley, S., \& Lynch, R. (2006). Volunteer management (2nd ed.). Johnstone Training and Consultation.

Naylor, H. (1973). Volunteers today: Finding, training and working with them. Dryden Associates.

Ouellette, K. L., Lesmeister, M. K., Lobley, J., \& Gross, K. M. (2014). e-Learning for 4-H volunteers: Who uses it, and what can we learn from them? Journal of Extension, 52(1). https://www.joe.org/joe/2014february/a5.php

Snider, A. S. (1985). The dynamic tension: Professionals and volunteers. Journal of Extension, 23(3). http://www.joe.org/ joe/1985fall/sa2.php

Western Connecticut State University. (n.d.). Benefits of community service. https://www.wcsu.edu/ community-engagement/benefits-of-volunteering/ 
Table 1. Recommended agenda for volunteer orientation.

\begin{tabular}{|c|c|c|}
\hline Component & $\begin{array}{l}\text { Primary Orientation } \\
\text { Component }\end{array}$ & Description and Overview \\
\hline Welcome & $\begin{array}{l}\text { Cause and Social } \\
\text { Orientation }\end{array}$ & $\begin{array}{l}\text { Opening led by lead volunteer trainer/comments from the organization's } \\
\text { director }\end{array}$ \\
\hline Introduction/icebreaker & Social Orientation & $\begin{array}{l}\text { Age-appropriate engagements that are intended to promote interaction } \\
\text { among participants }\end{array}$ \\
\hline Purpose of organization & Cause Orientation & Discuss the organization's purpose and how volunteers contribute \\
\hline Mission/vision of organization & Cause Orientation & $\begin{array}{l}\text { Provide volunteers with a copy (in print or electronic) of the organization's } \\
\text { mission and vision }\end{array}$ \\
\hline History of organization & Cause Orientation & Brief history of the organization from its creation to current day \\
\hline Organization clientele & Cause Orientation & $\begin{array}{l}\text { Provide information or personal stories of the clientele volunteers will be } \\
\text { working with }\end{array}$ \\
\hline Organizational chart & Social Orientation & $\begin{array}{l}\text { Provide volunteers with a copy of an organizational chart with individual } \\
\text { names of who they work with }\end{array}$ \\
\hline Timelines/calendar & Social Orientation & $\begin{array}{l}\text { Provide volunteers with a copy of the organization's timeline for achieving } \\
\text { goals and/or upcoming events }\end{array}$ \\
\hline $\begin{array}{l}\text { Overview of procedures, policies, } \\
\text { guidelines, rules, and benefits }\end{array}$ & System Orientation & $\begin{array}{l}\text { Provide volunteers with a copy of the organization's policies, procedures, } \\
\text { along with any changes }\end{array}$ \\
\hline Volunteer handbook & System Orientation & $\begin{array}{l}\text { Provide volunteers with a handbook with critical materials, forms, or } \\
\text { policies relevant to their work }\end{array}$ \\
\hline $\begin{array}{l}\text { Tour of facility/introduction to } \\
\text { staff }\end{array}$ & Social Orientation & $\begin{array}{l}\text { Guide volunteers around the organization and provide a map (e.g., } \\
\text { buildings, floors, outdoor areas, etc.) }\end{array}$ \\
\hline $\begin{array}{l}\text { Overview of further training } \\
\text { offered or required }\end{array}$ & System Orientation & $\begin{array}{l}\text { Provide volunteers with required training plans or optional training offered } \\
\text { as a benefit }\end{array}$ \\
\hline Time for questions and answers & Nonapplicable & $\begin{array}{l}\text { Provide ample time for volunteers to ask questions and provide contact } \\
\text { information for volunteers to use }\end{array}$ \\
\hline Refreshments/social networking & Social Orientation & $\begin{array}{l}\text { Socials with food are a great way to allow volunteers to interact with new/ } \\
\text { current volunteers and staff }\end{array}$ \\
\hline
\end{tabular}

